УДК 342.95:349.4

DOI https://doi.org/10.32849/2663-5313/2021.3.26

\title{
Григорій Грянка,
}

канд. юрид. наук, дочент,

доцент кафедри кримінального права, процесу та криміналістики

Київського інституту інтелектуальної власності та права

Начіонального університету «Одеська юридична академія»

\section{ЗЕМЕЛЬНІ ВІДНОСИНИ ЯК ОБ'ЄКТ ОХОРОНИ НОРМАМИ АДМІНІСТРАТИВНО-ДЕЛІКТНОГО ПРАВА}

Стаття присвячена комплексному дослідженню теоретичних та правових засад регулювання адміністративної відповідальності за правопорушення у сфері земельних відносин. Земля - частина навколишнього природного середовища, яка розташована на поверхні земної кори і характеризується грунтовим покривом, рельєфом, простором, рослинністю, надрами, водними об'єктами, є основним засобом виробництва у сільському і лісовому господарстві та місцем розташування об'єктів нерухомого майна.

Досліджено поняття «земельні відносини». Земельні правовідносини - че суспільні відносини, що існують у зв'язку зі здійсненням прав і законних інтересів власників землі та землекористувачів, їхніх обов'язків; діяльністю юрисдикиійних органів та інших суб'єктів щодо володіння, користування та розпорядження землею, ї рачіонального використання, відтворення та охорони.

Аналіз чинних нормативно-правових актів, наукових джерел дав можливість розкрити сутність та зміст земельних відносин, дослідити сучасний стан публічного управління ними. Земельні відносини становлять коло однорідних суспільних відносин: їх суб'єктами можуть бути фізичні, юридичні особи, органи державної влади та місиевого самоврядування, іноземні держави, міжнародні організаиії, громадські об'єднання та організації - носії суб'єктивних юридичних прав та обов'язків; їх загальним об'єктом є земля, а безпосередніми об'єктами можуть виступати земельні ділянки, земля як природний ресурс, у тому числі грунти, інформачія про землі; їх зміст становлять відносини права власності на землю та землекористування, їх рачіонального використання, відтворення та охорони, діяльності органів публічного управління відповідно до специфіки категорій земель, особливостей загального та безпосереднього об’єктів.

Встановлено склади адміністративних проступків, що вчиняються у сфері земельних відносин. Здійснено аналіз адміністративної відповідальності за иі проступки та запропоновано авторське бачення основоположних висновків, визначень, змін і доповнень до чинного законодавства, що покликані сприяти розв'язанню проблеми адміністративної відповідальності за правопорушення у сфері земельних відносин.

Ключові слова: земля, земельні відносини, Держгеокадастр, адміністративно-правове забезпечення.

Постановка проблеми. Перехід від адміністративно-директивної до ринкової економіки не може бути безболісним. Ситуація, що складається на місцях у процесі реформування земельних відносин, зумовлює низку проблем, про що свідчать факти невпинного збільшення випадків незаконного заволодіння земельними ділянками. Недостатньо реалізується одне з головних завдань земельної реформи - раціональне використання та охорона земель. Роботи щодо раціоналізації землекористування та охорони земель проводяться досить повільно, внаслідок чого деградація грунтового покриву деяких територій досягла критичного стану. Водночас сучасна система заходів адміністратив- ної відповідальності не здатна вплинути на оптимізацію землекористування та охорони земель, зменшилася кількість осіб, притягнутих до адміністративної відповідальності за псування і забруднення сільськогосподарських та інших земель. Отже, сьогодні виникла нагальна потреба в детальному дослідженні природи земельних відносин та їх нормативно-правового регулювання, а також у вивченні змісту правопорушень у цій сфері та особливостей застосування адміністративних санкцій за їх вчинення з метою удосконалення та підвищення ефективності інституту адміністративної відповідальності.

Методологічну основу для дослідження проблем теоретичних та правових засад регу- 
лювання адміністративної відповідальності за правопорушення у сфері земельних відносин заклали праці Г. М. Беженар, Є. С. Бердніков, В. К. Гуревський, В. К. Колпаков, О. В. Кузьменко та інші. Безпосередньо проблемам теоретичних та правових засад регулювання адміністративної відповідальності за правопорушення у сфері земельних відносин присвятили свої праці: О. Ю. Дрозд, Д. М. Лук'янець, Л. В. Мілімко, А. М. Мірошниченко, Н. І. Титова, М. В. Шульга. Праці згаданих авторів мають важливе наукове і практичне значення. Проте в них не приділялася достатня увага аналізу сутності та змісту земельних відносин, сучасному стану публічного управління ними, встановленню складів адміністративних проступків, що вчиняються у сфері земельних відносин, а також комплексному дослідженню причин та умов їх вчинення.

Мета статті - дослідити теоретичні та правові засади регулювання адміністративної відповідальності за правопорушення у сфері земельних відносин.

Виклад основного матеріалу. Відповідно до ст. 14 Конституції України земля $€$ основним національним багатством, що перебуває під особливою охороною держави. Право власності на землю гарантується. Запорукою виконання цих конституційних положень $є$ встановлення державою ефективного механізму забезпечення права на землю, важливим складником якого повинні бути й адміністративно-правові засоби, що передбачають відповідальність за порушення такого права [1].

Перехід від адміністративно-директивної до ринкової економіки не може бути безболісним. Ситуація, що складається на місцях у процесі реформування земельних відносин, зумовлює низку проблем, про що свідчать факти невпинного збільшення випадків незаконного заволодіння земельними ділянками: за даними Держгеокадастру за 2018 рік, здійснені 15594 перевірок дотримання вимог земельного законодавства, винесено 1932 клопотання, 5331 припис, 4542 протоколи, 4149 постанов про накладення адміністративних стягнень на суму 1,3 млн. грн., 1421 матеріал направлено до прокуратори [2]. Також недостатньо реалізується одне з головних завдань земельної реформи - раціональне використання та охорона земель. В Україні залишається найвищою у світі розораність сільськогосподарських угідь - 78 \%. Роботи щодо раціоналізації землекористування та охорони земель проводяться досить повільно, внаслідок чого деградація грунтового покриву деяких територій досягла критичного стану. Водночас сучасна система заходів адміністративної відповідальності не здатна вплинути на оптимізацію землекористування та охорони земель, що підтверджують конкретні статистичні дані (за 2015-2018 роки на $27 \%$ зменшилася кількість осіб, притягнутих до адміністративної відповідальності за псування і забруднення сільськогосподарських та інших земель). Такі фактичні показники суперечать проголошеному Земельним кодексом України положенню, що використання власності на землю не може завдавати шкоди правам і свободам громадян, інтересам суспільства, погіршувати екологічну ситуацію і природні якості землі [3].

Отже, сьогодні виникла нагальна потреба в детальному дослідженні природи земельних відносин та іх нормативно-правового регулювання, а також у вивченні змісту правопорушень у цій сфері та особливостей застосування адміністративних санкцій за їх вчинення з метою удосконалення та підвищення ефективності інституту адміністративної відповідальності.

Особливе місце в системі суспільних відносин посідають правові відносини. Їхня суть полягає у тому, що це відносини, які врегульовані нормами права, і їх учасники наділяються взаємними правами та обов'язками. Правові відносини становлять соціальний зв'язок; є наслідком свідомої вольової діяльності; виникають, припиняються або змінюються, як правило, на основі норм права; вони мають, як правило, двосторонній характер і є особливою формою взаємного зв'язку між конкретними суб'єктами через їхні права, обов'язки і відповідальність; охороняються державою і забезпечуються заходами державного впливу [4, с. 345-347].

Серед них виокремлюються правовідносини, об'єктом яких є землі. Згідно з пунктом 1 статті 2 Земельного кодексу (далі - ЗК) України, земельні відносини - це суспільні відносини щодо володіння, користування і розпорядження землею [5].

У наукових працях [6; 7] та ЗК України вживається термін «земельні відносини» як тотожний поняттю «земельні правовідносини», тобто використовується синонімічний ряд однотипних термінів. Водночас можна не погодитися 3 цією точкою зору, оскільки земельні відносини - це відносини загального плану, які не завжди урегульовані нормами права. Натомість земельні правовідносини - це суспільні відносини, що підлягають правовому регулюванню.

Земельні відносини регулюються переважно самостійною галуззю права - земельним правом. Із цього приводу Д. М. Лук'янець 
зазначає, що слід звернути увагу на той факт, що в значній кількості сфер реалізації виконавчої влади існує, крім адміністративно-правового, ще й цивільно-правове регулювання. Це стосується, перш за все, транспортної, енергетичної, будівельної, аграрної, земельної, банківської та багатьох інших сфер. 3 огляду на це, можна, поєднавши відповідні адміністративно-правові та цивільно-правові норми, отримати нові, так би мовити, предметні галузі права 3 аналогічними назвами Ці галузі права є результатом логічного розвитку двох зазначених фундаментальних галузей права. Їх (предметні галузі) не можна ставити поруч на один щабель у загальній структурі системи права 3 цивільним або адміністративним правом, оскільки вони $\epsilon$ результатом розвитку останніх [8, с. 101].

У ЗК України закріплено, що земельні відносини - це суспільні відносини щодо володіння, користування і розпорядження землею. У своїй сукупності повноваження щодо володіння, користування та розпорядження землею становлять зміст права власності і мають свої особливості в кожній формі власності на землю (державній, комунальній, приватній).

3 огляду на реальні обставини право власності на землю може бути обмежене законодавством. Обмеження прав на землю спричинені обмеженістю земельних ресурсів у природі й неможливістю їх заміни у процесі господарської діяльності [9, с. 125]. Основні обмеження прав на землю закріплені у статті 111 ЗК України, a саме: право на земельну ділянку може бути обмежене законом або договором шляхом встановлення: заборони на продаж або інше відчуження певним особам протягом установленого строку; заборони на передачу в оренду (суборенду); права на переважну купівлю у разі ії продажу; умови прийняття спадщини тільки визначеним спадкоємцем; умови розпочати і завершити забудову або освоєння земельної ділянки протягом встановлених строків; заборони на провадження окремих видів діяльності; заборони за заміну цільового призначення земельної ділянки, ландшафту та зовнішнього виду нерухомого майна; умови здійснити будівництво, ремонт або утримання дороги, ділянки дороги; умови додержання природоохоронних вимог або виконання визначених робіт; умови надавати право полювання, вилову риби, збирання дикорослих рослин на своїй земельній ділянці в установлений час i в установленому порядку; інших зобов'язань, обмежень або умов. Ці обмеження мають переважно адміністративно-правову природу, хоча в окремих випадках вони встановлюються нормами цивільного права. Виключно адміністративно-правовими засобами здійснюється державна реєстрація обмежень використання земельної ділянки, що діє протягом терміну, встановленого законом або договором.

Повноваження щодо володіння і користування землею становлять зміст права землекористування. Ці повноваження мають постійні користувачі земельними ділянками державної або комунальної власності (пункт 1 статті 92 ЗК України), тимчасові землекористувачі на основі строкового платного користування на умовах оренди (пункт 1 статті 93 ЗК України) та ін. Землекористувач у процесі їі використання, самостійно здійснюючи ці повноваження, повинен раціонально використовувати земельну ділянку, здійснювати заходи щодо її відтворення та охорони.

Крім цього, земельні правовідносини мають специфічні особливості залежно від цільового призначення земель. Так, відповідно до статті 19 ЗК України, землі в Україні за цільовим призначенням поділяються на такі категорії: сільськогосподарського призначення; житлової та громадської забудови; природно-заповідного та іншого природоохоронного призначення; оздоровчого призначення; рекреаційного призначення; історико-культурного призначення; лісового фонду; водного фонду; промисловості, транспорту, зв'язку, енергетики, оборони та іншого призначення.

Поняття «земля» у ЗК України не закріплено, однак закріплено в Законі України «Про охорону земель»: зокрема, у статті 1 визначено, що земля - це поверхня суші 3 грунтами, корисними копалинами та іншими природними елементами, що органічно поєднані та функціонують разом з нею [10]. На нашу думку, це поняття не відображає поняття землі як об'єкта правових відносин, а характеризує іï лише як природний ресурс, тому спробуємо з'ясувати значення цього поняття у правовому аспекті.

Термін «земля» прийнято розглядати у двох аспектах. Земля як земна куля, частина космічної матерії, планета Сонячної системи має природне походження, створена без участі людини і як природний дар належить усьому людству. Земля у цьому розумінні охоплює не лише її поверхню, але i надра та все з нею пов'язане (грунти, води (поверхневі та підземні), ліси, рослинний і тваринний світ та ін.) [11, с. 9].

У підручнику «Земельне право» (1949р.) за редакцією Н. Д. Казанцева і А. А. Рускола висловлено думку про те, що земля є всеза- 
гальною умовою праці, операційним базисом та основним засобом виробництва в деяких галузях народного господарства [12, с. 3-12].

у Державних стандартах «Земля. Терміни і визначення» земля трактується як найважливіша частина навколишнього природного середовища, що характеризується простором, рельєфом, грунтовим покривом, рослинністю, надрами, водами, є головним засобом виробництва у сільському господарстві, а також просторовою базою для розміщення галузей народного господарства [13].

Особливе розуміння досліджуваного поняття наведене Н. І. Титовою. Вона зазначає, що категорія «земля» це певною мірою особливий за походженням різновид майна, частина матеріального світу, відокремлена від природного середовища працею людини. Категорія «землі» в її розумінні - це природний компонент, органічна частина довкілля. На їі думку, лише як природний компонент і складова частина довкілля земля виступає об'єктом земельних відносин [14, с. 14]. Хоча ця позиція і не знайшла підтримки в наукових колах, на нашу думку, частіше термін «землі» вживається як узагальнене поняття об'єкта навколишнього природного середовища, а термін «земля» - коли йдеться про неї як об'єкт земельних, цивільних чи адміністративних правовідносин.

Земельне законодавство України містить велику кількість норм екологічної спрямованості (наприклад, стаття 167 ЗК України «Охорона земель від забруднення небезпечними речовинами», стаття 168 «Охорона грунтів», стаття 31 Закону України «Про охорону земель», яка визначає нормативи гранично допустимого забруднення грунтів та ін.). Об'єктом відносин, що закріплені у вказаних статтях, не є ані земельна ділянка, ані право на неї чи на земельний пай. У цьому разі об'єктом є земля саме як природний об'єкт чи природний ресурс, що характеризується екологічними ознаками. У нормативних актах він позначений двома термінами: «землі» чи «грунти». Саме як природний об'єкт земля виконує найважливіші функції: $€$ засобом виробництва в лісовому та сільському господарстві тощо.

Зокрема, В. К. Гуревський, Г. М. Беженар, Є. С. Бердніков та інші вчені наголошують на тому, що основним об'єктом використання земель є грунти, які відіграють особливу роль у сфері сільськогосподарського виробництва. Саме відносини щодо охорони грунтів є об'єктом правової охорони від протиправних посягань через вчинення адміністративних проступків, що полягають у псуванні й забрудненні сільськогосподарських та інших земель (стаття 52 КУПАП) або знятті та перенесенні грунтового покриву земельних ділянок без спеціального дозволу (стаття 53-3 КУПАП).

Статтями 22-25-1 Закону України «Про охорону навколишнього природного середовища» визначено, що джерелами інформації про стан навколишнього природного середовища є дані моніторингу, кадастрів природних ресурсів, реєстри, автоматизовані бази даних [15]

Інформація як об'єкт земельних відносин має як адміністративно-правову, так і цивільно-правову природу. Законодавчо визначено, що така інформація формується переважно спеціально уповноваженими органами управління (у земельних кадастрах, у реєстрах земельних ділянок, прав на них та обмежень на земельні ділянки тощо), а також міститься у цивільно-правових угодах (договорах купівлі-продажу, міни, оренди, земельного сервітуту, іпотеки тощо) Зміст правовідносин з приводу інформації про землі та права на них становлять сукупність прав та обов'язків заінтересованих суб'єктів у цій інформації. До таких суб'єктів, наприклад, можуть належати органи земельних ресурсів, покупці земельних ділянок, нотаріус, суд, органи прокуратури та ін. Саме суспільні відносини щодо надання повної і достовірної інформації про землі та права на них є безпосереднім об'єктом адміністративного проступку, передбаченого статтею 53-2 КУ ПАП.

Суб'єктами земельних відносин в Україні, згідно з п. 2 ст. 2 ЗК України, є громадяни, юридичні особи, органи місцевого самоврядування та органи державної влади. Тобто до кола суб'єктів Кодекс відносить осіб, які є суб'єктами права власності на землі й суб'єктами управлінських відносин та які наділені чинним законодавством відповідними правами й обов'язками.

Варто погодитися 3 точкою зору А. М. Мірошниченка, що не можна зводити коло учасників земельних правовідносин до суб̆'єктів права власності. За змістом прав та обов'язків їх поділяють на чотири категорії: органи державної влади і місцевого самоврядування, що мають право на регулювання використання земель; власники землі й землекористувачі - носії прав та обов'язків 3 раціонального використання й охорони земель; громадські екологічні об'єднання, наділені правом громадського контролю за використанням земель; органи судово-прокурорського нагляду, що здійснюють нагляд за законністю у сфері земельних правовідносин.

Отже, коло суб'єктів правовідносин у сфері володіння, користування і розпоря- 
дження землею є вужчим, ніж коло суб'єктів земельних правовідносин.

Земельні ресурси України - найдорожче багатство ії народу. Цінність землі як національного багатства полягає в її багатофункціональному призначенні. Навкруги нас немає нічого більш вічного, необхідного i незамінного, як земля. Вона є головним засобом виробництва в сільському господарстві та просторовим базисом розміщення та розвитку всіх інших галузей господарства. Про величезне значення землі говорить і те, що вона не є продуктом людської діяльності, вона - творіння самої природи, а тому збільшити запаси земельних ресурсів за бажанням чи потребою людини неможливо. Збільшення населення світу вимагає особливої уваги до раціонального використання й охорони земельних ресурсів, оскільки потрібно буде задовольняти потреби населення у сільськогосподарській продукції і створювати сприятливі умови для проживання людей.

Земельні правовідносини - це суспільні відносини, що виникають у зв'язку зі здійсненням прав і законних інтересів власників землі та землекористувачів, їхніх обов'язків; діяльністю юрисдикційних органів та інших суб'єктів щодо володіння, користування i розпорядження землею, а також її раціонального використання, відтворення та охорони.

Однією 3 основних природних ознак землі $\epsilon$ її нерухомість. Тому для визначення юридичної природи землі як об'єкта земельних відносин важливим є з'ясування співвідношення таких понять, як земля і нерухомість. Відповідно до ст. 13, 14 Конституції України термін «земля» вживається y самостійному значенні без будь-якого співвідношення з іншими об'єктами нерухомості. Водночас у ст. 142 Конституції України визначено, що матеріальною і фінансовою основою місцевого самоврядування $€$ рухоме і нерухоме майно, а також земля, що $€$ у власності територіальних громад. У теоpiї земельного права немає єдиного підходу до розуміння землі як нерухомості, в економічному і правовому розумінні земля та інші об'єкти природного походження не є майном, у зв'язку з чим вони в законодавчому порядку виокремленні із системи майнових відносин. На мою думку, земля - це різновид майна, але особливого за своїм походженням, екологічною, економічною, політичною, соціальною та державно-правовою цінністю. Тому в законодавстві доцільно запровадити таке поняття, як нерухома власність. У силу своїх об'єктивних факторів земля є нерухомістю, незалежно від того, чи розміщено на ній те або інше нерухоме майно. Усі інші об'єкти на землі визнаються нерухомістю, якщо їх не можна відокремити від землі без заподіяння значної шкоди. Таке розуміння співвідношення землі та розташованих на ній майнових об'єктів є загальноприйнятим і закріплюється у цивільному та земельному законодавстві багатьох зарубіжних держав, що є визначальним для регулювання земельних відносин, захисту майнових, фінансових, корпоративних та інших прав і охоронюваних законом інтересів власників землі [16, с. 25].

\section{Висновки}

Отже, земельні відносини становлять коло однорідних суспільних відносин: а) їх суб'єктами можуть бути фізичні, юридичні особи, органи державної влади та місцевого самоврядування, іноземні держави, міжнародні організації, громадські об'єднання та організації - носії суб'єктивних юридичних прав та обов'язків; б) їх загальним об'єктом є земля, а безпосередніми об'єктами можуть виступати земельні ділянки, земля як природний ресурс, у тому числі грунти, інформація про землі; в) їх зміст становлять відносини права власності на землю та землекористування, їх раціонального використання, відтворення та охорони, діяльності органів публічного управління, відповідно до специфіки категорій земель, особливостей загального та безпосереднього об’єктів. Саме суспільні відносини щодо надання повної і достовірної інформації про землі та права на них є безпосереднім об'єктом адміністративного проступку, передбаченого статтею 53-2 КУ ПАП.

\section{Список використаних джерел:}

1. Конституція України : Закон України від 28 черв. 1996 р. № 254к/96-ВР. Верховна Рада Украйни. URL: http://zakon2.rada.gov.ua/laws/ show/-254\%D0\%BA/96-\%D0\%B2\%D1\%80 (дата звернення: 18.02.2021).

2. Публічний звіт Держгеокадастру за 2018 рік. Держгеокадастр. 2019. URL: http://land.gov.ua/ wp-content/uploads/2018/03/pub_rep_2018.pdf. (дата звернення: 18.02.2021).

3. Мілімко Л. В. Адміністративна відповідальність за правопорушення у сфері земельних відносин : автореф. дис. ... канд. юрид. наук: 12.00.07. Ірпінь, 2009. 20 c.

4. Скакун О. Ф. Теорія держави і права : підручник. Харків: Консум, 2001. 656 с.

5. Земельний кодекс України : Закон України від 25 жовт. 2001 р. № 2768-III \Верховна Рада України. URL: https://zakon.rada.gov.ua/laws/ show/2768-14 (дата звернення: 18.02.2021).

6. Земельне право України : підручник / Гуревський В. К., Беженар Г. М., Бердніков Є. С. 
та ін.; за ред. О. О. Погрібного, I. I. Каракаша. Київ: Істина, 2003. 448 c.

7. Мірошниченко А. М. Земельне право України : навчальний посібник. Київ: Алерта, ЦУЛ, 2011. $678 \mathrm{c}$.

8. Лук'янець Д. М. Адміністративно-деліктні відносини в Україні: теорія та практика правового регулювання : монографія. Суми: ВДТ «Університетська книга», 2006. 367 с

9. Аграрное, земельное и экологическое право Украины. Общие части учебных курсов : учебное пособие / под ред. А. А. Погребного, И. И. Каракаша. Харьков: Одиссей, 2000. 368 с.

10. Про охорону земель : Закон України від 19 черв. 2003 р. № 962-IV. Верховна Рада Украӥни. URL: https://zakon.rada.gov.ua/laws/show/962-15 (дата звернення: 18.02.2021).

11. Шульга М. В. Актуальные правовые проблемы земельных отношений в современных условиях. Харьков: Фирма «Консум», 1998. $224 \mathrm{c}$.

12. Земельное право : учебник / сост. А. А. Рускол и др.; под ред. Н. Д. Казанцева, А. А. Рускола. Москва: Госюриздат, 1949. 415 с.

13. Охрана природы. Земля. Термины и определения : ГОСТ 17.5.1.05-80 : утвержден и введен в действие Постановлением Государственного комитета СССР по стандартам от 28 окт. 1985 г. № 3453.

14. Титова Н. I. Землі як об'єкт правового регулювання. Право Украӥни. 1998. № 4. С. 10-15.

15. Про охорону навколишнього природного середовища: Закон від 25 черв. 1991 р. № 1264XII / Верховна Рада України. URL: https://zakon. rada.gov.ua/laws/show/1264-12 (дата звернення: 18.02.2021).

16. Дрозд О. Ю. Земля як об'єкт земельних відносин. Адвокат. 2009. № 1. С. 24-26.

Hryhorii Hrianka. Land relations as an object of protection of the rules of administrative and tort law

The article is devoted to a comprehensive study of theoretical and legal principles of regulation of administrative responsibility for offenses in the field of land relations. Land - part of the environment, which is located on the surface of the earth's crust and is characterized by soil cover, terrain, space, vegetation, subsoil, water bodies, is the main means of production in agriculture and forestry and the location of real estate objects.

The concept of «land relations» is investigated. Land relations are social relations that have to do with the exercise of the rights and legitimate interests of landowners and land users, their responsibilities; activities of jurisdictions and other entities in the possession, use and disposal of land, its rational use, reproduction and protection.

The analysis of the existing normative legal acts, scientific sources made it possible to reveal the nature and content of land relations, to explore the current state of public management of them. Land relations constitute a circle of homogeneous social relations: subjects may be individuals, legal entities, state and local governments, foreign states, international organizations, public associations and organizations - holders of subjective legal rights and duties; the common object of which is land and the immediate objects may be land, land as a natural resource, including soils, land information; their content is the relationship of land ownership and land use, their rational use, reproduction and protection, the activities of public authorities, in accordance with the specifics of land categories, features of general and direct objects.

The composition of administrative misconduct committed in the field of land relations has been established. The analysis of administrative responsibility for these offenses is carried out and the author's vision of the basic conclusions, definitions, changes and amendments to the current legislation, which are intended to contribute to solving the problem of administrative liability for offenses in the field of land relations, is proposed.

Key words: land, land relations, Geocadastre, administrative and legal support. 